\title{
The clitic binding restriction revisited: Evidence for antilogophoricity
}

\section{Citation}

Charnavel, Isabelle, and Victoria Mateu. 2015. “The Clitic Binding Restriction Revisited: Evidence for Antilogophoricity." The Linguistic Review 32 (4) (January 1). doi:10.1515/tlr-2015-0007.

\section{Published Version}

doi:10.1515/ttr-2015-0007

\section{Permanent link}

http://nrs.harvard.edu/urn-3:HUL.InstRepos:34330193

\section{Terms of Use}

This article was downloaded from Harvard University's DASH repository, and is made available under the terms and conditions applicable to Open Access Policy Articles, as set forth at http:// nrs.harvard.edu/urn-3:HUL.InstRepos:dash.current.terms-of-use\#OAP

\section{Share Your Story}

The Harvard community has made this article openly available.

Please share how this access benefits you. Submit a story.

\section{Accessibility}




\section{The Clitic Binding Restriction Revisited: Evidence for Antilogophoricity Isabelle Charnavel (Harvard) and Victoria Mateu (UCLA)}

Some languages such as French and Spanish exhibit an interesting coreference restriction in clitic clusters. Consider the sentences in (1) ${ }^{1}$ and (2): in (1), the accusative clitic $l a$ 'her' in the embedded clause can refer to the subject of the matrix clause, Anna. However, when the accusative clitic is clustered with a dative clitic as in (2), coreference with Anna is impossible

a. Anne , croit $q u^{\prime}$ on va la $a_{i j} \quad$ recommander au patron pour la Anna thinks that s.o.will ACC.3FSG recommend to.the boss for the promotion. promotion

b. Ana $_{i}$ cree que la $a_{i j}$ recomendarán al jefe para el Anna thinks that ACC.3FSG recommend.FUT.3PL to.the boss for the ascenso. promotion

'Anna $a_{\mathrm{i}}$ thinks that they will recommend her $\mathrm{i}_{\mathrm{ij}}$ to the boss for the promotion.'

a. Anne $e_{i}$ croit qu' on va la $*_{i j}$ lui $i_{k}$ recommander, [au patron] $]_{k}$, Anna thinks that s.o.will ACC.3FSG DAT.3SG recommend to.the boss pour la promotion. for the promotion

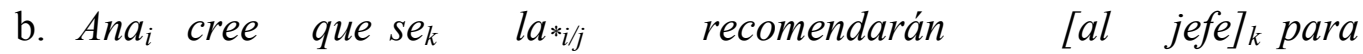
Anna thinks that DAT.3 ACC.3FSG recommend.FUT.3PL to.the boss for el ascenso. the promotion

'Anna ${ }_{\mathrm{i}}$ thinks that they will recommend her ${ }_{*_{i} / j}$ to him $\mathrm{k}_{\mathrm{k}}-[\text { the boss }]_{\mathrm{k}}-$ for the promotion.'

The only previous account of this constraint (Bhatt and Šimík 2009) attributes it to binding: when an accusative clitic is clustered with a dative clitic, the accusative clitic cannot be bound. Based on new data experimentally controlled, we will instead show that the constraint is due to antilogophoricity. That is, the antecedent of an accusative clitic in a double object clitic construction may not be a logophoric center, i.e. a perspective center, or

\footnotetext{
* For their comments, suggestions and feedback, we are grateful to two anonymous reviewers and the audiences of the UCLA Syntax/Semantics Seminar, WCCFL 32 and GLOW 37; a special thanks to Dominique Sportiche for very helpful discussion on this project. We are also greatly indebted to all the participants who completed our linguistic survey. This work was supported in part by the National Science Foundation under grants 1424054 and 1424336.

${ }^{1}$ Unless otherwise noted, (a) examples correspond to French and (b) examples to Spanish throughout the paper. Note that in French, extraposition will be used to specify the reference of dative clitics.

Abbreviations are standard: ACC: accusative, COND: conditional, DAT: dative, EXPL: expletive, FUT: future, GEN: genitive, LOC: locative, NOM: nominative, PL: plural, PRS: present, PST: past, REFL: reflexive, s.o.: someone, SG: singular, SBJV: subjunctive.
} 
the one whose speech, thoughts, or feelings are being reported. We will derive this restriction from perspective conflicts, which will be analyzed as intervention effects in the presence of a single logophoric operator in the relevant domain. Specifically, we will argue that dative clitics generally occupy a position encoding 'empathy', and that when an accusative clitic refers to an attitude holder and co-occurs in the same cluster, this results in a conflict of perspectives. This analysis furthermore provides a semantic motivation for intervention effects that have been postulated for the Person-Case-Constraint (PCC, Bonet 1991), which we will hypothesize also derives from conflicting centers of perspective.

After providing more details about the empirical facts of this clitic cluster restriction and its previous account (Section 1), we will lay out our experimental study (Section 2), which will lead us to our analysis based on antilogophoricity (Section 3).

\section{Background}

\subsection{A deeper look into the data}

The constraint on accusative clitics in clusters observed in (2) is not only found in French and Spanish - the target languages of this paper - but also in Catalan, Czech, and Serbo-Croatian among others (see Bhatt and Śimík 2009). It emerges in specific conditions that concern both the dative clitic and the antecedent of the accusative clitic. First, the constraint arises whether the dative clitic is a goal (3), a benefactor (4) or a possessor (5). ${ }^{2}$

a. * Pierre $_{i}$ dit qu' on le $e_{i} \quad$ lui $_{k}$ a présenté, à [la Reine $]_{k}$. Peter says that s.o. ACC.3MSG DAT.3SG has introduced to the Queen

b. ${ }^{*}$ Pedro $_{i}$ dice que se lo $_{i} \quad$ presentaron a [la Reina $]_{k}$.

Peter says that DAT.3 ACC.3MSG introduce.PST.3PL to the Queen

'Peter ${ }_{\mathrm{i}}$ says that they introduced him $_{\mathrm{i}}$ to her $_{\mathrm{k}}-[\text { the Queen }]_{\mathrm{k}}$.'

a. ${ }^{*}$ Pierre $_{i}$ dit qu' on le lui $_{k}$ a peint, (pour [la Reine] ${ }_{k}$ ). Peter says that s.o. ACC.3MSG DAT.3SG has painted for the Queen b. ${ }^{*}$ Pedro $_{i}$ dice que $\mathrm{se}_{k} \quad \mathrm{lo}_{i} \quad$ pintaron (a lla Reina $]_{k}$ ). Peter says that DAT.3 ACC.3MSG paint.PST.3PL to the Queen

'Peter ${ }_{i}$ says that they painted him $_{i}$ for her ${ }_{k}\left([\text { the Queen }]_{k}\right)$.'

a. ${ }^{*}$ Pierre $_{i}$ craint qu' on ne le lui $i_{k}$ mette dans les bras (de Peter fears that s.o. EXPL ACC.3MSG DAT.3SG put in the arms of [la nounou $]_{k}$ ).

the nanny

b. ${ }^{*}$ Pedro teme que se $_{k} \quad$ lo $o_{i} \quad$ pongan en los brazos de [la niñera] . $_{\text {. }}$ Peter fears that DAT.3 ACC.3MSG put.SBJV.3PL in the arms of the nanny

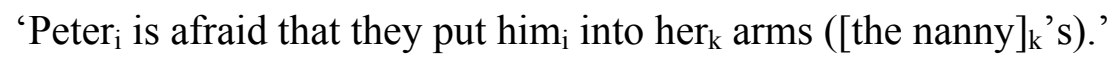

\footnotetext{
${ }^{2}$ In some dialects of French, clitic clusters display the order dative $>$ accusative. Based on preliminary results, this does not seem to have an effect on the constraints stated in this section.
} 
But there is no restriction on the accusative clitic when the dative is a full DP, as in (1), further exemplified in (6), a strong pronoun, as in the French example in $(7)^{3}$, a locative clitic, as in the French example in $(8)^{4}$, or an ethical dative, as in the Spanish example in (9). ${ }^{5}$

a. Pierre $_{i}$ dit qu'on $l_{i}^{\prime} \quad a$ présenté à [la Reine]. Peter says that s.o. ACC.3SG has introduced to the Queen

b. Pedro ${ }_{i}$ dice que lo $_{i} \quad$ presentaron a [la Reina].

Peter says that ACC.3MSG introduce.PST.3PL to the Queen

'Peter ${ }_{i}$ says that they introduced him $_{i}$ to the Queen.'

Pierre $_{i}$ dit qu'on $l_{i}^{\prime} \quad$ a présenté à elle (pas à lui $i_{k}$ ).

Peter says that s.o. ACC.3SG has introduced to her not to him

'Peter $r_{i}$ says that they introduced him $_{\mathrm{i}}$ to HER (not $\mathrm{HIM}_{\mathrm{k}}$ ).'

Pierre $_{i}$ dit qu'on $l_{i}^{\prime} \quad y_{k} \quad$ a emmené, [au château $]_{k}$. Peter says that s.o. ACC.3MSG LOC has taken to.the castle

'Peter ${ }_{\mathrm{i}}$ says that they took him $_{\mathrm{i}}$ there $_{\mathrm{k}}$ - to [the castle $]_{\mathrm{k}}$.'

Jesús $_{i}$ dijo a $\left[\mathrm{su}\right.$ madre $_{k}$ que se lo $_{i}$ vendieron a los

Jesus said to her mother that DAT.3SG ACC.3MSG sell.PST.3PL to the enemigos.

enemies

'Jesus $\mathrm{i}_{\mathrm{i}}$ said to [her mother $]_{\mathrm{k}}$ that they sold him $\mathrm{i}_{\mathrm{i}}$ to the enemies on her $\mathrm{k}_{\mathrm{k}}$.'

Furthermore, the constraint is only observed when the accusative clitic has an antecedent, such as Peter, in the same sentence, but not if it is in the previous sentence (10) or utterance. The clitic cluster is also acceptable if Peter antecedes the dative clitic instead of the accusative clitic, as in (11), or if neither clitic corefers with the subject, as in (12).

a. (Voici Pierre $)_{i}$. On va le lui $e_{k}$ présenter, [à la Reine] ${ }_{k}$. here.is Peter ${ }_{i}$ S.o. will ACC.3MSG DAT.3SG introduce to the Queen

b. (Este es Pedro). Se lo lo presentarán $e_{i}$ la Reina $]_{k}$. (this is Peter) DAT.3 ACC.3MSG introduce.FUT.3PL to the Queen

'This is Peter ${ }_{i}$. They will introduce him $_{\mathrm{i}}$ to her $\mathrm{h}_{\mathrm{k}}-[\text { the Queen }]_{\mathrm{k}}$ '.

\footnotetext{
${ }^{3}$ Clitic doubling of dative pronouns is obligatory in Spanish.

${ }^{4}$ There is no locative clitic in Spanish.

${ }^{5}$ Ethical datives are generally restricted to 1 st and 2nd persons in French (Jouitteau \& Rezac 2008, a.o.) and Spanish (Ormazabal \& Romero 2007), and as we will see in Section 2.4. Results and Discussion, there is no coreference restriction when the dative clitic is a $1 \mathrm{st} / 2 \mathrm{nd}$ person in any case. However, there are cases where we can find 3rd person ethical datives co-occurring with other clitics in Spanish as shown in (9) (see Franco \& Huidobro 2008). Crucially, ethical dative clitics do not give rise to the constraint whichever person they are, and as we will see in Section 3 Proposal, this is so because they do not occupy the same position as regular datives, which encodes point of view, but a higher position outside the logophoric domain.
} 
(11) a. Pierre $e_{i}$ dit qu' on la la $a_{i}$ a présentée, [la Reine] . $_{\text {. }}$ Peter says that s.o. ACC.3FSG DAT.3SG has introduced the Queen

b. Pedro dice que $\mathrm{se}_{i}$ la $a_{k} \quad$ presentaron - $\left[\begin{array}{ll}l a & \text { Reina }]_{k} \text {. }\end{array}\right.$ Peter says that DAT.3 ACC.3FSG introduce.PST.3PL the Queen 'Peter ${ }_{i}$ says that they introduced her ${ }_{k}$ to $\operatorname{him}_{\mathrm{i}}-[\text { the Queen }]_{\mathrm{k}}$ '.

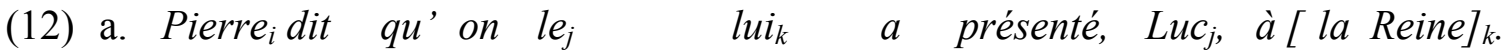
Peter says that s.o. ACC.3MSG DAT.3SG has introduced Luke to the Queen

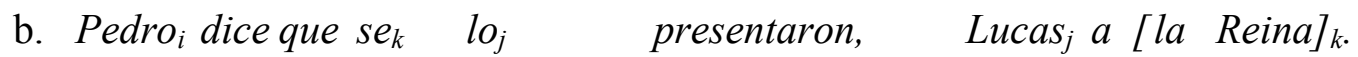
Peter says that DAT.3 ACC.3MSG introduce.PST.3PL Luke to the Queen 'Peter ${\text { says that they introduced } \text { him }_{\mathrm{j}} \text { to her }}_{\mathrm{k}}-\mathrm{Luke}_{\mathrm{j}}$ to [the Queen] $]_{\mathrm{k}}$ '

In sum, it seems that an accusative clitic cannot be anteceded by a DP in the same sentence when it is clustered with a dative clitic that is a goal, a benefactor or a possessor. It remains to be seen in more detail which conditions the antecedent must fulfill to trigger the constraint. This is our main departure from the previous analysis of this phenomenon, i.e. Bhatt and Šimík’s (2009).

\subsection{Previous Account}

First observed by Roca (1992) via Kayne, and Ormazabal and Romero (2007), the phenomenon described above has received very little attention in the literature. The only attempt - to our knowledge - to account for this constraint is that of Bhatt and Šimík (2009), who crucially attribute it to a binding restriction, as defined in (13).

Clitic Binding Restriction (CBR)

When a [third person] indirect object (IO) clitic and a direct object (DO) clitic co-occur in a cluster, the DO clitic cannot be bound.

Bhatt and Šimík (2009) derive this constraint from the Person Case Constraint (see Adger and Harbour 2003; Albizu 1997; Anagnostopoulou 2003, 2005; Béjar and Rezac 2003; Bianchi 2003; Bonet 1991 1994; Ormazabal and Romero 2002, inter alia), defined in (14) and instantiated in (15) vs. (16).

Person Case Constraint (PCC, Strong version)

In a combination of a weak direct object and an indirect object [clitic, agreement marker, or weak pronoun], the direct object has to be a third person (Bonet 1991: 182).

(15) a. *Pierre me lui a recommandé.

Peter ACC.1SG DAT.3SG has recommended

b. *Pedro se me recomendó.

Peter DAT.3SG ACC.1SG recommended

'Peter recommended me to him.' 
(16) a. Pierre me l'a a recommandé.

Peter DAT.1SG ACC.3SG has recommended

b. Pedro me lo recomendó.

Peter DAT.1SG ACC.3SG recommended

'Peter recommended him to me.'

Bhatt and Šimík (2009) propose that third person clitics acquire features as a result of variable binding, triggering PCC effects. More precisely, they adopt the core idea of the standard hypotheses accounting for PCC, namely that third person pronouns come in two forms - a featurally more specified variant and a featurally underspecified variant - and PCC requires the accusative clitic to be featurally underspecified. Under feature-checking approaches, this is so because the presence of a structural intervener (dative clitic) blocks certain agree relations between the Probe and the accusative clitic (see Anagnostopoulou 2003, 2005; Adger and Harbour 2007; Heck and Richards 2007). Under hierarchy-based approaches, the ungrammaticality comes from failure of alignment between two hierarchies: the thematic/argument structure hierarchy and the person hierarchy (see Rosen 1990; Haspelmath 2004).

Drawing on the idea that variable binding involves feature transmission (see Kratzer 2009) and that grammar favors binding over coreference (see Reinhart's [1983] Rule I and Roelofsen's [2010] Rule S), Bhatt and Šimík (2009) claim that accusative third person pronouns, which usually lack inherent features of the sort that PCC cares about, acquire these features as a result of variable binding, thus triggering PCC effects. Specifically, they implement this idea assuming the existence of two hierarchies: the person hierarchy $H:\{1>3,2>3$, Bound $3>3\}$ and the argument structure hierarchy: indirect object $>$ direct object. Clitics have to respect both hierarchies, which fails in the case at hand and gives rise to the ungrammaticality we observe. For instance in (3), the accusative clitic le/lo acquires features because it is bound by Peter. It is thus higher than the dative clitic lui/se on the person hierarchy, but lower than it on the argument structure hierarchy; this discrepancy causes the ungrammaticality of the clitic cluster.

This analysis predicts that binding of the dative clitic rescues a bound accusative clitic. This is what Bhatt and Šimík (2009: 7) call the 'weak CBR effect', which they observe in French in (17) (Bhatt and Šimík 2009: 8) and in Czech.

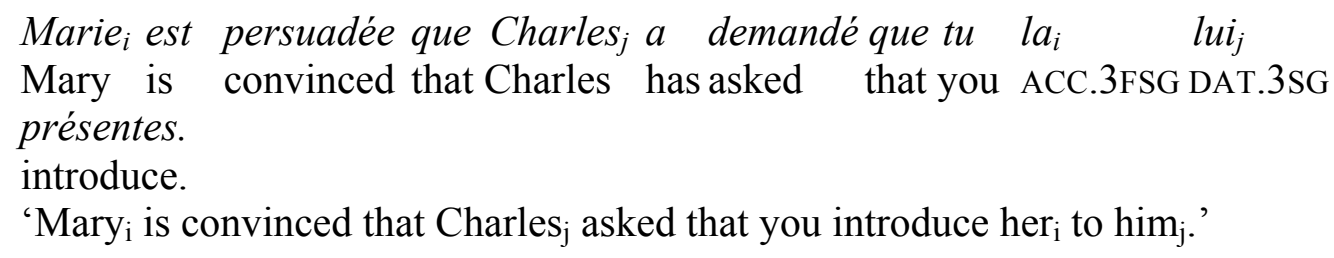

In sum, under Bhatt and Šimík's approach, binding of the accusative clitic is crucially responsible for CBR effects, which derive from PCC. 


\section{Experimental Study}

The goal of our experimental study was to question Bhatt and Šimík's (2009) conclusion. Using a grammaticality judgment task we investigated the conditions under which the restriction on clitic clusters arises, and in particular, whether binding of the accusative clitic is the crucial factor. In what follows we provide the details of our experimental study, the results of which argue against this view.

\subsection{Hypothesis}

On close scrutiny, it appears that there is a non-negligible confound in the examples that instantiate the clitic cluster constraint in the literature: they all involve psychverbs and verbs of saying whose subjects typically have perspective over the sentential complement. We thus hypothesize that binding by itself is not the relevant factor, but rather, antilogophoricity constraints on the accusative clitic antecedent. That is, the antecedent of the accusative clitic cannot be logophoric.

The notion of logophor was coined by Hagège (1974) to designate certain pronominal forms in West-African languages that appear in specific environments such as indirect discourse as illustrated in (18) for Ewe.
a. Kofi bey yè-dzo.
Kofi say LOG-leave
'Kofi $i_{i}$ said that he ${ }_{\mathrm{i}}$ left.'
b. Kofi bey e-dzo.
Kofi say 3SG-leave
'Kofi ${ }_{i}$ said that (s)he ${ }_{k}$ left.'

According to Clements (1975: 130), the antecedent of logophors must be the center of perspective, i.e. "the one whose speech, thoughts, feelings, or general state of consciousness are reported". More precisely, Sells (1987) proposes to distinguish between three types of logophoric antecedents as in (19), which have been reported to be crucial for licensing long distance anaphors such as Mandarin Chinese ziji (Huang and Liu 2001, inter alia) or Icelandic sig (Maling 1984, inter alia) among others.

(19) a. Source: the one who is the intentional agent of the communication.

b. Self: the one whose mental state or attitude the proposition describes.

c. Pivot: the one with respect to whose (time-space) location the content of the proposition is evaluated.

We hypothesize that the relevant notion of logophoric center for the clitic cluster restriction is that of attitude holder, corresponding to Sells' (1987) Source and Self: we suppose that the antecedent of the accusative clitic cannot be an attitude holder.

To test our hypothesis against Bhatt and Šimík's (2009), we construct an experiment disentangling the two crucial variables, viz., binding and logophoricity. In 
other words, for the constraint to arise, should the antecedent bind the accusative clitic or be an attitude holder?

\subsection{Participants}

A total of 97 adult French native speakers participated in the French version of this study. They were all born and raised in France and were aged between 23 and 76 ( $M$ $=40.1$ ). Additionally, 35 adult Spanish native speakers participated in the Spanish version of this study. They were all born and raised in Spain or Mexico, and were aged between 23 and $59(M=28.9)$.

\subsection{Materials and Method}

Participants had to provide grammaticality judgments on a continuous scale online. They were asked to click towards the right edge of the bar if the sentence sounded natural, or towards the left edge of the bar of it did not sound natural. Subjects were also asked to pay close attention to the reference of the pronouns, indicated in parenthesis after the sentence. There were three training items involving clitics, and six control items with full DPs as the indirect object. We employed a between-subjects design so that no participant was presented with both the test item and the corresponding control sentence. The task included twenty-seven test items with clitic clusters, as well as six control items with an accusative clitic and a full DP indirect object. ${ }^{6}$ The test sentences were constructed around the following four variables (and the control sentences around the first two, see Table 1):

i. whether the accusative clitic has a c-commanding antecedent or a non-commanding antecedent;

ii. whether the accusative clitic antecedent is a logophoric center or a non-logophoric center;

iii. whether the dative clitic is a local first/second person or a non-local third person; and

iv. whether the dative clitic has a c-commanding antecedent or a non-commanding antecedent.

With respect to the second variable, we ensured that the antecedent is an attitude holder by using intensional predicates (e.g. 'think', 'believe') or intensional expressions (e.g. 'according to', 'someone's letter'). Concerning the last variable, aimed to test for Bhatt and Šimík's (2009) weak CBR effect, we guaranteed binding of the dative clitic by using quantifiers as in (20). Note that to avoid lengthening the experiment unnecessarily, we only manipulated that variable when relevant, namely, when the accusative clitic was

\footnotetext{
${ }^{6}$ Since it was virtually impossible for naive subjects to infer the purpose of the study and the character of the different variables no fillers were included. Moreover, adding the necessary number of fillers to hide the pattern of manipulation, i.e. 2:1, would have lengthened the experiment significantly and unnecessarily.
} 
also bound (by a logophoric center). ${ }^{7}$

(20) a. [L' actrice $]_{i}$ a promis à [chaque figurant $]_{k}$ que les producteurs The actress haspromised to each extra that the producers la $a_{i} \quad$ lui $_{k} \quad$ présenteraient. ACC.3FSG DAT.3SG introduce.COND.3PL

b. [La actriz $]_{i}$ prometió a [cada extra $]_{k}$ que los productores se $e_{k} \quad l a_{i}$ The actress promised to each extra that the producers DAT.3SG ACC.3FSG presentarian. introduce.COND.3PL

'[The actress $]_{\mathrm{i}}$ promised to [each extra $]_{\mathrm{k}}$ that the producers would introduce her $_{\mathrm{i}}$ to $\operatorname{him}_{\mathrm{k}}$.'

Table 1. Test conditions of the grammaticality judgment task.

\begin{tabular}{cccc} 
Condition & $\begin{array}{c}\text { C-commanding } \\
\text { antecedent }\end{array}$ & $\begin{array}{c}\text { Logophoric } \\
\text { center as } \\
\text { antecedent }\end{array}$ & $\begin{array}{c}\text { Person of } \\
\text { dative clitic }\end{array}$ \\
\hline 1 & yes & yes & 3 \\
2 & yes & yes & $1 / 2$ \\
3 & yes & yes & bound 3 \\
4 & yes & no & 3 \\
5 & yes & no & $1 / 2$ \\
6 & no & yes & 3 \\
7 & no & yes & $1 / 2$ \\
8 & no & no & 3 \\
9 & no & no & $1 / 2$ \\
Control 1 & yes & yes & N/A \\
Control 2 & no & yes & N/A
\end{tabular}

\subsection{Results and Discussion}

First, the results obtained from the French and Spanish grammaticality judgment tasks confirm the clitic cluster effect: participants gave lower scores in conditions 1, 3 and 6 as compared to the control sentences with a full DP as indirect object. Pairedsample t-tests confirmed that this difference was statistically significant for both French $(p<0.001)$ and Spanish $(p<0.001)$.

\footnotetext{
${ }^{7}$ It is thus understood that only condition 3 (see Table 1) had a bound dative clitic. In the other conditions the dative clitic was free.
} 
Table 2. Results of the grammaticality judgment task (the asterisk indicates that the sentences in that condition received a significantly lower score than the control sentences).

\begin{tabular}{ccccc} 
Condition & $\begin{array}{c}\text { C-commanding } \\
\text { antecedent }\end{array}$ & $\begin{array}{c}\text { Logophoric } \\
\text { center as } \\
\text { antecedent }\end{array}$ & $\begin{array}{c}\text { Person of } \\
\text { dative clitic }\end{array}$ & Grammaticality \\
\hline 1 & yes & yes & 3 & $*$ \\
2 & yes & yes & $1 / 2$ & OK \\
3 & yes & yes & bound 3 & $*$ \\
4 & yes & no & 3 & OK \\
5 & yes & no & $1 / 2$ & OK \\
6 & no & yes & 3 & $*$ \\
7 & no & yes & $1 / 2$ & OK \\
8 & no & no & 3 & OK \\
9 & no & no & $1 / 2$ & OK
\end{tabular}

Furthermore, the results in conditions 4 and 6 crucially show that it is logophoricity, not binding, that is relevant for this restriction on clitic clusters (contra Bhatt and Šimík 2009). As we predicted, CBR effects arise when the antecedent of the accusative clitic is a logophoric center, even if it does not c-command the accusative clitic (condition 6), as we see in examples (21)-(22) where the boy and the prisoner are attitude holders, but do not bind the accusative clitic.

a. ${ }^{*} D^{\prime}$ après $\quad\left[l^{\prime} \text { enfant }\right]_{i}$, les maîtresses vont le $e_{i} \quad l u i_{k} \quad$ confier, à according.to the child the teachers will ACC.3MSG DAT.3SG entrust to $\left[l^{\prime} \text { assistante }\right]_{k}$. the assistant

b. *Según [el niño] ${ }_{i}$, las maestras se $_{k} \quad l o_{i}$ encomendarán a according.to the boy the teachers DAT.3 ACC.3MSG entrust.FUT.3PL to [la asistenta $]_{k}$. the assistant

'According to [the child $]_{\mathrm{i}}$, the teachers will entrust him $\mathrm{i}_{\mathrm{i}}$ to her $\mathrm{k}_{\mathrm{k}},-[\text { the assistant }]_{\mathrm{k}}$.'

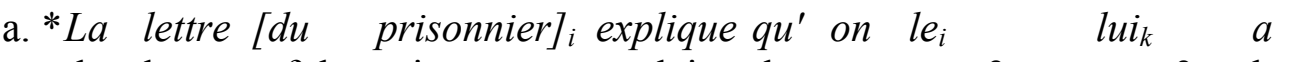
the letter of.the prisoner explains that s.o. ACC.3MSG DAT.3SG has livré sans preuve, [au juge $]_{k}$. handed without evidence to.the judge

b. ${ }^{*} L a$ carta [del prisionero] $]_{i}$ explica que $\mathrm{se}_{k} \quad \mathrm{lo}_{i}$ entregaron the letter of.the prisoner explains that DAT.3 ACC.3MSG hand.PST.3PL [al juez $]_{k}$ sin pruebas. to.the judge without evidence

'[The prisoner]'s letter explains that they handed him ${ }_{i}$ over to $\operatorname{him}_{k}-[$ the judge $]_{\mathrm{k}}-$ without evidence.' 
Conversely, we do not observe CBR effects when the antecedent c-commands the accusative clitic but is not a logophoric center (condition 4), as we see in (23) where the antecedent is inanimate and thus cannot be a perspective center, or in (24) where the antecedent is animate but is not an attitude holder. Note that this last case confirms that Sells' (1987) category Pivot is not relevant here. That is, pivot antecedents do not give rise to the constraint as opposed to Source and Self (attitude holders).
a. [Le paquet] $]_{i}$ spécifie qu' il faut le $e_{i}$
lui $_{k} \quad$ remettre, $[\mathrm{au}$

the package indicates that it must ACC.3MSG DAT.3SG give to.the concierge $]_{k}$.

doorman

b. [El paquete $]_{i}$ especifica que $\mathrm{se}_{k} \quad \mathrm{lo}_{i} \quad$ entreguen [al portero $]_{k}$. the package indicates that DAT.3 ACC.3MSG give SBJV.3PL to.the doorman

'[The package $]_{\mathrm{i}}$ specifies that they should hand $\mathrm{it}_{\mathrm{i}}$ over to him $_{\mathrm{k}}-$ [the doorman $]_{\mathrm{k}}$.'

(24) a. [Le criminel $]_{i} s^{\prime}$ est échappé avant qu' on ne le $e_{i}$ lui $_{k}$ the criminal REFL is escaped before that s.o. EXPL ACC.3MSG DAT.3SG livre, [au directeur $]_{k}$

hand to.the director

b. [El criminal $]_{i}$ huyó antes de que $\mathrm{se}_{k} \quad \mathrm{lo}_{i}$ entregaran the criminal escaped before of that DAT.3 ACC.3MSG hand.SBJV.3PL [al director $]_{k}$ to.the director '[The criminal $]_{\mathrm{i}}$ escaped before they handed him ${ }_{\mathrm{i}}$ over to $\operatorname{him}_{\mathrm{k}}-[\text { the director }]_{\mathrm{k}}$ '

Furthermore, the results of condition 3 reveal that binding of the dative clitic does not rescue a bound accusative pronoun as claimed by Bhatt and Simík's (2009). Thus, the weak CBR effect is invalidated in French and Spanish. We suspect that the reduction of CBR effects in sentences such as (17) may be due to the fact that Charles is an intervening perspective center. That is, in the relevant domain, Charles, not Mary, is a logophoric center. This indirectly supports our antilogophoricity hypothesis.

Finally, we also do not observe CBR effects when the antecedent of the accusative clitic is a logophoric center but the dative clitic is a first or second person pronoun (conditions 2 and 7) as shown in (25). These cases will be discussed in more detail in Section 3.5.1.

(25) a. [La petite fille] $]_{i}$ espère qu' on va te la confier. the little girl hopes that s.o. will DAT.2SG ACC.3FSG entrust

b. [La niña pequeña $]_{i}$ espera que te $e_{k} \quad l a_{i} \quad$ entreguen $\quad\left[\begin{array}{ll}a & t i\end{array}\right]_{k}$ the girl little hopes that DAT.2SG ACC.3FSG entrust.SBJV.3PL to you '[The little girl $]_{i}$ hopes that that they will entrust her $r_{i}$ to you.' 


\section{Proposal}

By disentangling binding and logophoricity, our experimental study provides evidence in support of the idea that accusative clitics are antilogophoric when clustered with third person dative clitics. In view of these results, we propose to replace Bhatt and Simík's (2009) CBR with the following generalization:

\section{Clitic Logophoric Restriction (CLR)}

When a third person dative clitic and an accusative clitic co-occur in a cluster, the accusative clitic cannot corefer with a logophoric center.

Further evidence in support of this hypothesis comes from parallel constructions with other antilogophors, such as epithets, as well as the fact that CLR effects only emerge when the pronoun is read de se. These are discussed in the following two sections. Subsequently, we will present our proposal.

\subsection{Antilogophoricity Effects}

Antilogophoricity effects have also been observed for epithets (Dubinsky and Hamilton 1998) or certain French pronouns like en/y (Ruwet 1990) as illustrated in (27) and (28) respectively.

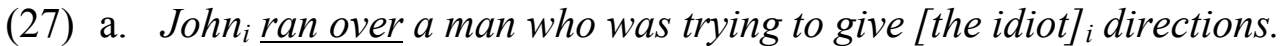

b. *John ${ }_{i}$ told us of a man who was trying to give [the idiot] $]_{i}$ directions.

(28) a. Emile mérite que Sophie en $_{i}$ tombe amoureuse.

Emile deserves that Sophie GEN falls in.love

'Emile ${ }_{\mathrm{i}}$ deserves it - that Sophie falls in love with himi.'

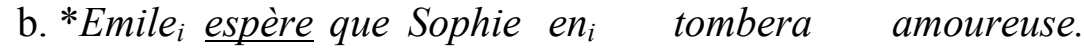

Emile hopes that Sophie GEN fall.FUT.3SG in.love

'Emile ${ }_{i}$ hopes that Sophie will fall in love with him ${ }_{\mathrm{i}}$.'

In (27a), the epithet the idiot can refer to John, which is not logophoric since it is the subject of the non-intensional predicate run over. By contrast, in (27b), John, which is the subject of the intensional verb tell, cannot antecede the idiot. The same contrast holds with the French pronoun en in (28), which can refer to the subject of the non-attitude verb mérite 'deserves', but not to the subject of the attitude verb espère 'hopes'.

Thus, we can use these other cases of antilogophoricity effects as diagnostics. By comparing a structure with a clitic cluster and a parallel one with an epithet, we can test whether the antecedent is a logophoric center. For instance, examples in (29), which contain epithets, are just as ungrammatical as their counterparts in (21) (repeated below), which involve clitic clusters. On the other hand, (30) with an epithet is as acceptable as its counterpart with a clitic cluster, (24) (repeated below). Crucially, the former cases, unlike the latter, involve coreference with a logophoric center. 
(21) a. *D'après [l'enfant $]_{i}$, les maîtresses vont le $e_{i} \quad l u i_{k} \quad$ confier, à according.to the child the teachers will ACC.3MSGDAT.3SG entrust to $\left[l^{\prime} \text { assistante }\right]_{k}$.

the assistant

b. *Según [el niño] ${ }_{i}$, las maestras se $_{k} \quad l o_{i}$ encomendarán a according.to the boy the teachers DAT.3 ACC.3MSG entrust.FUT.3PL to [la asistenta] . $_{\text {. }}$ the assistant

'According to [the child $]_{\mathrm{i}}$, the teachers will entrust him $\mathrm{i}_{\mathrm{i}}$ to her $\mathrm{k}_{\mathrm{k}},-[\text { the assistant }]_{\mathrm{k}}$.'

(29) a. *D'après [l'enfant], les maîtresses vont confier [le coquin] ì̀ according.to the child the teachers will entrust the brat to the l' assistante. the assistant

b. *Según [el niño], las maestras encomendarán [el mocoso $]_{i}$ a according.to the boy the teachers entrust.FUT.3PL the brat to la asistenta. the assistant

'According to [the child $]_{\mathrm{i}}$, the teachers will entrust [the brat $]_{\mathrm{i}}$ to the assistant.'

(24) a. [Le criminel $]_{i} s^{\prime}$ est échappé avant qu' on ne le $e_{i} \quad l u i_{k}$ the criminal REFL is escaped before that s.o. EXPL ACC.3MSG DAT.3SG livre, [au directeur $]_{k}$. hand to.the director

b. [El criminal] $]_{i}$ huyó antes de que $\mathrm{se}_{k} \quad \mathrm{lo}_{i}$ entregaran the criminal escaped before of that DAT.3 ACC.3MSG hand.SBJV.3PL [al director $]_{k}$. to.the director '[The criminal $]_{\mathrm{i}}$ escaped before they handed him over to him $_{\mathrm{k}}-[\text { the director }]_{\mathrm{k}}$ '

(30) a. [Le criminel] ${ }_{i} s^{\prime}$ est échappé avant qu' on ne livre [le crétin] the criminal REFL is escaped before that s.o. EXPL hand the bastard au directeur.

to.the director

b. [El criminal] huyó antes de que entregaran [el cabrón]i al the criminal escaped before of that hand.SBJV.3PL the bastard to.the director. director

'[The criminal $]_{i}$ escaped before the guards handed over [the bastard $]_{i}$ to the director.'

This diagnostic allows us to make the right predictions for sentences like (31) with relative clauses (cf. Bhatt and Šimík 2009: 3), where the logophoric status of the antecedent is not obvious in the absence of a standard attitude verb. The unavailability of 
the epithet in (32) confirms that the ungrammaticality of the clitic cluster in (31) comes from the logophoricity of John.

a. *Jean ${ }_{i} a$ vu la fille qui le $e_{i} \quad l u i_{k}$ a présenté, [au Pape] $k_{\text {. }}$ John has seen the girl who ACC.3MSG DAT.3SG has introduced, to.thePope

b. *Juan ${ }_{i}$ vio a la chica que se $k_{k} l_{i}$ presentó [al Papa $]_{k}$.

John saw to the girl who DAT.3 ACC.3MSG introduced, to.the Pope

' $\mathrm{John}_{\mathrm{i}}$ saw the girl who introduced him to him $_{\mathrm{k}}-$ [the Pope $]_{\mathrm{k}}$.'

(32) a. *Jeani $a$ vu la fille qui a présenté [l'idiot]iau Pape. John has seen the girl who has introduced the idiot to.the Pope

b. *Juan ${ }_{i}$ vio a la chica que presentó $\left[e l\right.$ idiota $_{i}$ al Papa. John saw to the girl who introduced the idiot to.the Pope

' $\mathrm{John}_{\mathrm{i}}$ saw the girl who introduced [the idiot $]_{\mathrm{i}}$ to the Pope.'

\subsection{De se readings}

We further observe that CLR effects do not simply arise when the antecedent of the accusative clitic is an attitude holder. More specifically, the accusative clitic also has to be read de se (cf. Chierchia 1989). If we force a non-de se interpretation of the antecedent, CLR effects disappear, as exemplified in (33).

(33) An intern is participating in the assignment of all the interns for the summer. Instead of names, the list has numbers. When asked where to assign intern \#1234567, the intern, who does not know it is her, suggests assigning that intern to Dr. Edmonds:

a. [L' interne $]_{i}$ a suggéré qu' on la lai $i_{k}$ assigne, [au the intern has suggested that s.o. ACC.3FSG DAT.3SG assign to.the Dr. Edmonds] $]_{k}$.

Dr. Edmonds

b. [La interna $]_{i}$ sugirió que $\mathrm{se}_{k} \quad l a_{i}$ asignaran the intern suggested that DAT.3 ACC.3FSG assign.SBJV.3PL [al Dr. Edmonds] $]_{k}$. to.the Dr. Edmonds '[The intern $]_{\mathrm{i}}$ suggested to assign her $\mathrm{r}_{\mathrm{i}}$ to him $\mathrm{k}_{\mathrm{k}},-[\text { Dr. Edmonds }]_{\mathrm{k}}$.'

This provides further evidence for antilogophoricity, since logophors are often characterized as de se elements (Anand 2006; Huang and Liu 2001; Schlenker 2003). ${ }^{8}$ This also means that CLR effects more precisely correspond to anti de se effects.

\footnotetext{
${ }^{8}$ Some African logophors have nevertheless been shown not to require a de se reading (see Pearson 2015).
} 


\subsection{Hypothesis: antilogophoricity effects derive from perspective conflicts}

We propose that the antilogophoricity effects responsible for CLR derive from conflicts of perspectives. This phenomenon is found in Mandarin with respect to the logophoric long-distance anaphor ziji: two instances of ziji in a single clause must corefer (Huang and Liu 2001: 7) as shown in (34).

(34) a. Zhangsan renwei Lisi $_{k}$ zhidao [Wangwu ba ziji i deshu song-gei-le ziji $i_{i}$ de Zhangsan think Lisi know Wangwu BA self's books gave-to-PFV self's pengyou] friends

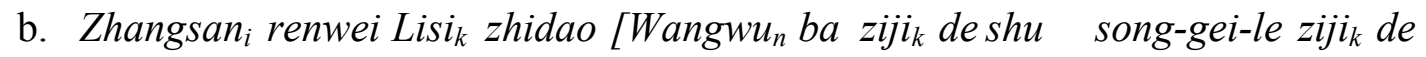
Zhangsan think Lisi know Wangwu BA self's books gave-to-PFV self's pengyou] friends

c. *Zhangsan ${ }_{i}$ renwei Lisi $i_{k}$ zhidao [Wangwu ba ziji $i_{i}$ de shu song-gei-le ziji $i_{k}$ de Zhangsan think Lisi know Wangwu BA self's books gave-to-PFV self's pengyou] friends

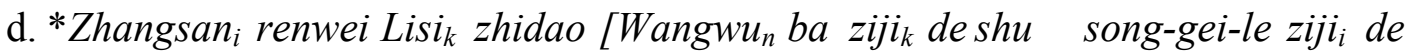
Zhangsan think Lisi know Wangwu BA self's books gave-to-PFV self's pengyou] friends

'Zhangsan thinks that Lisi knows that Wangwu gave self's books to self's friends.'

In the case of French and Spanish clitic clusters, we hypothesize that perspective conflicts arise between accusative clitics referring to perspective centers and dative clitics because dative clitics are inherently logophoric. In other words, our proposal consists of two hypotheses: (i) dative clitics always encode perspective; (ii) accusative and dative clitics belong to the same logophoric domain.

The hypothesis that dative clitics occupy a position encoding point of view is supported by several facts. First, dative clitics, as opposed to indirect object full DPs and locative clitics, generally have to be animate, which is a necessary condition for being a logophor. ${ }^{9}$ This is the case when dative clitics are goals as in (35) and (36), inalienable

\footnotetext{
${ }^{9}$ In Spanish there exists a type of inanimate dative clitics, namely, possessor datives. In these cases the dative can be inanimate "in so far as the theme can be(come) part of it" (Cuervo 2003: 69), as exemplified by Demonte's (1995: 12) sentences below:

i. Le puse el mantel a la mesa.

DAT.3SG put.PRS.1SG the tablecloth to the table

'I put the tablecloth on the table'

ii.*Le puse los platos a la mesa.

DAT.3SG put.PRS.1SG the dishes to the table

'I put the dishes on the table'

However, Cuervo argues that these should be analyzed as (static) possessors and not arguments affected by the verb. Thus, they involve a different low applicative (Appl-AT) than recipient datives (APPL-TO), which are the ones under study here.
} 
possessors as in (37), or benefactors as in (38) from Kayne (1975: 137), where the grandfather has to be alive. Note also that this animacy condition on dative clitics is reflected in Ormazabal and Romero's (2007) analysis of PCC in Spanish, which assigns an Animacy/Gender feature to dative clitics.

(35) a. Jean lui $i_{i} / \quad y_{i} \quad$ a envoyé une lettre, à Marie $_{i} / * \grave{a}$ Barcelone B $_{i}$. John DAT.3SG/LOC has sent a letter to Maria/ to Barcelona

b. Juan le ${ }_{i}$ envió una carta a María $/ *$ a Barcelona. John DAT.3SG sent a letter to Mary/ to Barcelona 'John sent her $\mathrm{i}_{\mathrm{i}}-$ Mary $_{\mathrm{i}}-\mathrm{a}$ letter.' / 'John sent $\mathrm{it}_{\mathrm{i}}-$ Barcelona $_{\mathrm{i}}-\mathrm{a}$ letter.'

(36) a. Sarah *lui/ y préfère/ compare cette maison, à cette maison-là. Sarah DAT.3sG/LOC prefers/ compares this house to that house-there b. * Sarah le prefierel compara esta casa a esa otra Sarah DAT.3SG prefers/ compares this house to that other 'Sarah prefers/compares this house to it - that other (house).'
a. Je lui ai marché sur le pied/*la branche.
I DAT.3SG have stepped on the foot/ the branch
b. Le pisé el pie/*la rama.
DAT.3SG step.PST.1SG the foot/ the branch

'I stepped on his foot/its branch.'

(38) a. Il lui $i_{i}$ achète cette pierre.tombale (à [songrand-père] $]_{i}$ ). he DAT.3SG buy that tombstone to his grandfather

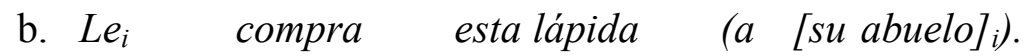
DAT.3SG buy.PRS.3SG that tombstone to his grandfather

'He is buying that tombstone for $\mathrm{him}_{\mathrm{i}}$ (his grandfather) ${ }_{\mathrm{i}}$.'

Furthermore, certain facts support the idea that more specifically, dative clitics encode point of view. When entering into constructions with verbs requiring dative case marking on the semantic subject (e.g. quirky displacement or quirky subjects) such as French plaire or Spanish gustar 'please' in (39), dative clitics refer to experiencers, which are perspective centers.
a. Jean lui plaît, à Marie.
John DAT.3SG pleases to Mary
b. A María le gusta él.
to Mary DAT.3SG likes NOM.3SG
'Mary likes him - John.'

When alternating with a locative clitic in French as in (40), the dative clitic yields a more perspectival interpretation than the locative clitic $y$ (Rooryck p.c.): in the case with lui, 
Luke must personally feel part of the team, while in the case with $y$, Luke's team membership is simply an objective description.

$$
\begin{aligned}
& \text { Luc lui/ y appartient, à cette équipe. } \\
& \text { Luke DAT.3SG/LOC belongs to this team } \\
& \text { 'Luke belongs to it - this team.' }
\end{aligned}
$$

Based on these observations, it seems reasonable to suppose that dative clitics in French and Spanish must be inherently logophoric. Note that PCC analyses based on feature checking make similar assumptions in specifying dative clitics for person (e.g. Adger and Harbour's [2003] [ \pm participant $]$ and $[ \pm$ empathy $]$ features; Anagnostopoulou's [2003, 2005] [ \pm person/participant] feature; Boeckx's [2000] [ \pm person] feature; Reinhart's [2000] [ \pm mental state] feature, inter alia) as opposed to accusative 3rd person clitics that are assumed to lack a [person/participant] feature altogether (Anagnostopoulou 2003; Adger and Harbour 2007). This is outlined in (41).

$$
\begin{array}{ll}
\text { 1st person: } & {[+ \text { person/+participant }]} \\
\text { 2nd person: } & {[+ \text { person/+tparticipant }]} \\
\text { 3rd person dative: } & \text { [-person/-participant }] \\
\text { 3rd person accusative: } & \text {------- }
\end{array}
$$

Japanese may give us an insight into the kind of logophoric center that dative clitics can correspond to, namely so-called empathy locus. It has been reported that some Japanese verbs such as the transferring verbs yaru and kureru 'give' alternate depending on the viewpoint from which the event is described. In the case of yaru, the event is described from the point of view of the referent of the subject or the neutral point of view, while in the case of kureru, the event is described from the point of view of the referent of the dative object. Thus, in (42a), kureru, as opposed to yaru, is incompatible with a nominative first person: the speaker, from whose perspective the event is described, must be expressed by a dative pronoun in the case of kureru, as in (42a), but by a nominative pronoun in the case of yaru, as in (42b).

\section{a. Boku ga Hanako ni okane o \{*kure-rulya-ru\} I NOM Hanako DAT money ACC give-PRS 'I give money to Hanako.'}

b. Tarooga boku ni okane o \{kure-ru/*ya-ru\}. Taroo NOM me DAT money ACC give-PRS

'Taroo gives me money.'

In cases involving kureru, the dative is characterized as an empathy locus, i.e. the event participant with whom the speaker empathizes/identifies (see Kuno 1987, and Oshima 2007). Similarly, we hypothesize that dative clitics in French and Spanish can be empathy loci, i.e. they may refer to a specific type of logophoric center different from attitude holders. This does not mean that dative clitics cannot refer to attitude holders: empathic elements are in fact compatible with attitudinal interpretations as illustrated in 
(11); this simply means that attitude holders and empathy loci are two types of logophoric centers (see Charnavel 2014), and dative clitics must be one of them.

Recall that crucially, CLR effects only arise with dative clitics, not with full DPs as indirect objects. Under this approach, this implies that indirect object full DPs are not necessarily logophoric as opposed to dative clitics. In fact, they are not subject to the animacy requirement as illustrated in (43) and (44) to be compared to (35) and (36) respectively. The same holds for the counterparts of (37) and (38).

(43) a. Jean a envoyé une lettre à Barcelone. John has sent a letter to Barcelona

b. Juan envió una carta a Barcelona. John sent a letter to Barcelona

'John sent a letter to Barcelona.'

(44) a. Sarah préfère/compare cette maison-ci à cette maison-là. Sarah prefers/ compares this house to that house-there

b. Sarah prefiere/ compara esa casa a esa otra. Sarah prefers/ compares this house to that other

'Sarah prefers/compares this house to that other (house).'

This parallels the contrast between ditransitive constructions and double object constructions in English (cf. Baker 1996; Stowell 1981). That is, inanimate indirect objects can only participate in the former, not in the latter as exemplified in (45).

(45) a. John sent a letter to Barcelona.

b. *John sent Barcelona a letter.

Based on this observation and drawing on Anagnostopoulou's (2003) analysis, we hypothesize that only clitic constructions (as opposed to ditransitive constructions with full DPs) qualify as double object constructions in Romance languages, in the sense of including an applicative head (vAppl; Marantz 1993). Arguments for this distinction besides animacy - include possibilities of nominalization and possibilities of movement in raising and passive constructions (see Anagnostopoulou 2003 for details; see also Demonte 1995 for arguments specific to Spanish). In sum, our hypothesis is that dative clitics occupy a position encoding empathy, because they enter into a double object construction, while indirect object full DPs appear in a different construction that does not force an empathy interpretation.

The second component of our hypothesis that CLR effects derive from perspective conflicts is that dative and accusative clitics belong to the same logophoric domain. Assuming that there is only one logophoric center in the relevant domain (Koopman and Sportiche 1989; Huang and Liu 2001; Sundaresan 2012), the attitude holder (accusative clitic) and the empathy locus (dative clitic) compete as logophoric centers, thus yielding ungrammaticality. However, note that this domain must exclude the subject, since a logophoric accusative clitic clustered with a subject clitic does not trigger CLR as shown in (46). 
(46) a. Pierre $e_{i}$ dit qu'il $l_{i} \quad l u i_{k} \quad a$ présenté son fils, à [la Reine] ${ }_{k}$. Peter says that NOM.3SG DAT.3SG has introduced his son to the Queen.

b. Pedro dice que él $l_{i}$ le $_{k}$ presentó su hijo a [la Reina] $]_{\text {. }}$ Peter says that NOM.3SG DAT.3SG introduced his son to the Queen.

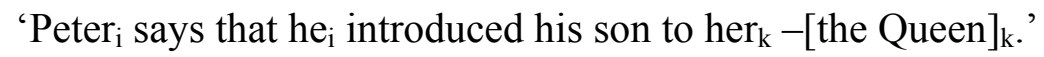

The domain we consider as relevant in French and Spanish is thus the one represented in (47).

(47) a. French (see Sportiche's French clitic template [1996: 5])

$\begin{array}{lcc}\text { NOM } & \text { [3.ACC } & \text { 3.DAT }] \\ \text { il/elle/je } & \text { le/la } & \text { lui } \\ \text { b. Spanish } & & \\ \text { Nom } & \text { [3.DAT } & \text { 3.ACC }] \\ \text { él/ella/yo } & \text { se/le } & \text { lo/la }\end{array}$

\subsection{Person Case Constraint}

This hypothesis provides us a way to derive PCC from a semantic constraint. Instead of deriving CLR from PCC as Bhatt and Šimík (2009) do, we assume that PCC, like CLR, derives from a ban on several conflicting centers of perspective in the same domain. Strikingly, PCC directly arises if we follow Kuno's (1987) direct discourse representation hypothesis. If we transpose a sentence that violates CLR into direct discourse, we observe PCC effects. Compare sentence (2), repeated below, with sentence (48). In (48), a perspective conflict arises between the inherently logophoric dative lui/se and the speaker $m e$, a discourse participant, which is inherently a perspective center.

(2) a. *Anne e $_{i}$ croit qu' on va la lui $i_{k}$ recommander, [au patron $]_{k}$, Anna $_{\text {i }}$ thinks that s.o.will ACC.3FSG DAT.3SG recommend to.the boss pour la promotion. for the promotion

b. ${ }^{*}$ Ana $_{i}$ cree que se $e_{k} \quad l a_{j} \quad$ recomendarán $\quad[a l l j e f e]_{k}$ para Anna $_{\mathrm{i}}$ thinks that DAT.3 ACC.3FSG recommend.FUT.3PL to.the boss for el ascenso.

the promotion

'Anna $a_{\mathrm{i}}$ thinks that they will recommend her ${ }_{*_{i} j}$ to him ${ }_{k}-[\text { the boss }]_{k}-$ for the promotion.'

(48) a. Anne pense: “*on va me lui recommander [...]".

Anna thinks: s.o. will ACC.1SG DAT.3SG recommend

b. Ana piensa: "*se me recomendarán [...]".

Anna thinks: DAT.3SG ACC.1SG recommend.FUT.3PL

"Anna thinks: "they will recommend me to him."” 
Further evidence for this hypothesis comes from the fact that PCC can be overridden when the first person is not read de se. This is possible in the case of dream reports, such as the one in example (49).

(49) a. ?J $J_{i}$ ai rêvé que j'étais Marilyn Monroe ${ }_{m}$, que j'étais chez Kennedy

I have dreamed that I was Marilyn Monroe that I was house Kennedy

et que je me $_{i} \quad$ lui $_{k} \quad$ présentais.

and that I ACC.1SG DAT.3SG introduced

b. ?Yo soñé que era Marilyn Monroe ${ }_{m}$, que estaba encasa de

I dreamed that be.PST.1SG Marilyn Monroe that be.PST.1SG in house of

Kennedy $y_{k}$ que $s_{k} \quad m e_{i} \quad$ presentaba.

Kennedy and that DAT.3SG ACC.1SG introduce.PST.1SG

' $\mathrm{I}_{\mathrm{i}}$ dreamed that I was M. Monroe $\mathrm{m}_{\mathrm{m}}$, that I was at Kennedy's house and that $\mathrm{I}_{\mathrm{m}}$ introduced $\mathrm{me}_{\mathrm{i}}$ to him $_{\mathrm{k}}$.'

The relevant logophoric domain for clitics can thus be specified as follows.
a. French
$\begin{array}{lccc}\text { Nom } & {[1 / 2 . \mathrm{DAT}} & \text { 3.ACC } & \text { 3.DAT } \\ \text { il/elle/je } & \mathrm{me} / \mathrm{te} & \text { le/la } & \text { lui }\end{array}$
b. Spanish

\begin{tabular}{|c|c|}
\hline $\begin{array}{l}\text { Nom } \\
\text { l/ella/vo }\end{array}$ & {$\left[\begin{array}{c}\text { 1/2.DAT } \\
\mathrm{me} / \mathrm{te}\end{array}\right.$} \\
\hline
\end{tabular}

\subsection{Analysis}

\subsubsection{First/second person dative clitics}

The discussion above suggests that any first/second person clitic gives rise to a perspective conflict when clustered with a logophoric clitic. But recall conditions 2 and 7 of our experimental study: there is no CLR effect when the antecedent of the accusative clitic is a logophoric center and the dative clitic is a first or second person pronoun as shown in (25), repeated below.
a. [La petite fille $]_{i}$ espère qu' on va te la confier. the little girl hopes that s.o. will DAT.2SG ACC.3FSG entrust
b. [La niña pequeña] $]_{i}$ espera que te la entreguen a ti. the girl little hopes that DAT.2SG ACC.3FSG entrust.SBJV.3PL to you '[The little girl $]_{\mathrm{i}}$ hopes that that they entrust her ${ }_{\mathrm{i}}$ to you.'

Furthermore, since French and Spanish have the strong version of PCC as explained in (51), this means that the correlation between PCC and CLR is imperfect as observed by Bhatt and Šimík (2009): transposing (25) into a direct discourse yields the ungrammatical sentence (52) showing a PCC effect. 
(51) a. Strong version of PCC: *1/2.Accusative.Clitic Dative.Clitic

b. Weak version of PCC: *1/2.Accusative.Clitic 3.Dative.Clitic

(52) a. La petite fille pense: "*on va te me confier." the little girl thinks s.o. will DAT.2SG ACC.1SG entrust

b. La niña pequeña piensa: "*te me entregarán a ti." the girl little thinks DAT.2SG ACC.1SG entrust.FUT.3PL to you

'The little girl thinks: "they will entrust me to you".'

To account for this, we assume that all interactions between logophoric centers are not equal. Namely, the different types of logophoric centers form a hierarchy and only two adjacent elements on the hierarchy create perspective conflicts.

\subsubsection{Hierarchy of logophoric centers}

First, we suppose the classification of logophoric centers in (53) (cf. Charnavel 2014).

(53) a. Discourse participant: The speaker and addressee of the actual discourse, i.e. 1/2 person clitics.

b. Empathy locus: The event participant with whom the speaker empathizes or identifies (see Kuno 1987; Oshima 2007), e.g. 3rd person dative clitics. It involves direct integration of perspective.

c. Attitude holder: The event participant whose discourse or thoughts are being reported, e.g. 3rd person accusative clitics read de se. It involves indirect integration of perspective.

We moreover hypothesize a hierarchy of logophoric centers based on the degree of perspective integration in the discourse as in (54).

$$
\text { discourse participant }>\text { empathy locus }>\text { attitude holder }
$$

Discourse participants and empathy loci both involve the speaker (directly or by identification) while empathy loci and attitude holders both involve a perspective center different from the speaker (implicitly or explicitly). Note that these roles are not exclusive: elements that are intrinsically high logophoric centers on the hierarchy can be used as lower logophoric centers. For instance, dative clitics, which are inherently empathy loci, can also refer to attitude holders as in (11).

Antilogophoricity effects emerge, we propose, when two identical or adjacent logophoric centers on this hierarchy co-occur in the domain represented in (50). Specifically, CLR effects arise when an empathy locus (third person dative clitic) and an attitude holder (third person accusative clitic read de se) appear in the same domain, and PCC effects emerge when a discourse participant (first/second person clitics) and an empathy locus (third person dative clitic) co-occur. Table 3 summarizes the various possibilities of clitic combinations correctly predicted by our analysis. 
Table 3. Grammaticality of clitic combinations in French and Spanish

\begin{tabular}{|c|c|c|c|}
\hline Predictions & \multicolumn{2}{|c|}{ Grammaticality } & \multirow[t]{2}{*}{ Violation } \\
\hline Logophoric centers in the domain & French & Spanish & \\
\hline * discourse participant + discourse participant & *me/te me/te & $\mathrm{me} / \mathrm{te} \mathrm{me} / \mathrm{te}$ & PCC \\
\hline$* \mathrm{~d}$ & *me & *se 1 & PCC \\
\hline * empathy locus + empathy locus & *me/te lui & *se me/te & PCC \\
\hline * attitude holder (read de se) + empathy locus & *le lui & *se lo & CLR \\
\hline $\begin{array}{l}* \text { attitude holder }(\text { read } d e s e)+\text { attitude holder } \\
\text { discourse participant }+ \text { attitude holder (read } d\end{array}$ & $\begin{array}{l}* \text { le lui } \\
\text { me/te le }\end{array}$ & $\begin{array}{l}{ }^{*} \text { se lo } \\
\text { me/te lo }\end{array}$ & CLR \\
\hline
\end{tabular}
se)

\subsubsection{Further issue: reflexives}

Reflexives pattern exactly like first and second person clitics (cf. Kayne 2000, who shows that they belong to the same morphological class). In first place, they trigger PCC effects when clustered with a dative clitic (see Bonet 1991) whether third person as in (55) (weak PCC) or first/second person as in (56) (strong PCC).
a. * ${ }^{*}$ interne se lui assigne.
the intern REFL DAT.3SG assigns
b. *La interna se le asigna.
the intern REFL DAT.3SG assigns

'The intern assigns herself to him.'

(56) a. * $L$ ' interne se $m$ ' assigne.

the intern REFL DAT.1SG assigns

b. ${ }^{*}$ La interna se me asigna.
the intern REFL DAT.1SG assigns

'The intern assigns herself to me/me to herself.'

Secondly, dative reflexive clitics do not trigger CLR effects as exemplified in (57).

(57) a. [L' interne $]_{i}$ a suggéré que le Dr. Edmonds $s_{k}$ se $_{k} \quad l_{i}^{\prime}$

the intern has suggested that the Dr. Edmonds REFL ACC.3FSG

assigne.

assign.SBJV.3SG

b. [La interna] $]_{i}$ sugirió que el Dr. Edmonds $s_{k} e_{k} l a_{i}$ asignara. the intern suggested that the Dr. Edmonds REFL ACC.3FSG assign.SBJV.3PL '[The intern $]_{\mathrm{i}}$ suggested that Dr. Edmonds $\mathrm{k}_{\mathrm{k}}$ assigns her $\mathrm{i}_{\mathrm{i}}$ to himself $\mathrm{f}_{\mathrm{k}}$.'

And lastly, they occur in the same position as first and second person clitics relatively to other clitics. 
(58)
a. French
NoM
il/elle/je
[ 1/2.DAT/REFL
3.ACC
le/la
3.DAT ]
lui
b. Spanish

$\left.\begin{array}{cccc}\text { Nom } & {[1 / 2 . \mathrm{DAT} / \mathrm{ReFL}} & \text { 3.DAT } & \text { 3.ACC } \\ \text { él/ella/yo } & \mathrm{me} / \mathrm{te} / \mathrm{se} & \mathrm{se} / \mathrm{le} & \text { lo/la }\end{array}\right]$

This leads us to hypothesize that reflexives behave like discourse participants with respect to logophoricity. This is supported by certain facts suggesting that reflexives have a first person component. Comparable to Mandarin ziji (see Huang and Liu 2001), reflexives in French and Spanish are speaker-inclusive when there is no antecedent as illustrated in (59).
a. Se remettre en question est souvent une bonne idée.
REFL.3SG to.question in question is often a good idea
b. Cuestionarse-se es a.menudo una buena idea to.question-REFL.3SG is often a good idea
'To question oneself is often a good idea.'

Similarly, the long distance reflexive French $s o i$ 'oneself' must be speaker-inclusive as shown in (60) (cf. Moltmann [2006]'s analysis of one(self) as a first-person generic pronoun).

(60) a. On $n_{i}$ pense souvent que les étrangers ont peur de soi $i_{\text {. }}$. s.o. thinks often that the foreigners are scared of oneself 'People $\mathrm{i}_{\mathrm{i}}$ often think that foreigners are afraid of them.

b. *Là-bas, on ${ }_{i}$ pense que les étrangers ont peur de soi $i_{\text {. }}$. there s.o. thinks that the foreigners are scared of oneself 'Over there, they $\mathrm{i}_{\mathrm{i}}$ think that foreigners are afraid of them $\mathrm{m}_{\mathrm{i}}$.'

\subsection{Implementation}

We propose to represent perspective conflicts as intervention effects due to Closest Attract/Agree (Chomsky 1995, 1998). A logophoric center intervenes when another logophoric center occurs in the same domain, because both enter a featurechecking relation with one and the same logophoric operator. More specifically, intervention effects arise when two logophoric centers share the same feature(s).

This implementation first requires the existence of logophoric operators instantiating logophoric centers. As proposed by Koopman and Sportiche (1989), Anand (2006) and Sundaresan (2012), logophoric operators are similar to silent pronouns that are coreferential (or in a relation of non-obligatory control) with the antecedent and bind logophoric elements as represented in (61), thereby triggering de se readings. According to Anand (2006), this is the case because the operator is in the immediate complement of a referential item that denotes the de se center. 
Antecedent $_{\mathrm{i}}$

Moreover, like Koopman and Sportiche (1989) and Sundaresan (2012), we hypothesize that there is at most one logophoric operator c-commanding the relevant domain, as represented in (62).
a. French
NOM OPLOG
il/elle/je
[1/2.DAT/REFL $\mathrm{me} / \mathrm{te} / \mathrm{se}$
3.ACC
le/la
3.DAT ]
b. Spanish
Nom OPLOG
él/ella/yo
[1/2.DAT/REFL $\mathrm{me} / \mathrm{te} / \mathrm{se}$
3.DAT
3.ACC ]
lo/la

Assuming a feature-checking mechanism between interpretable features on logophoric elements and uninterpretable features on logophoric operators, two logophoric elements sharing the same feature(s) give rise to an intervention effect. To explain why two adjacent or identical logophoric centers on the hierarchy share features, we assume the system of features in (63) to be linked to the properties of logophoric centers described in (53).

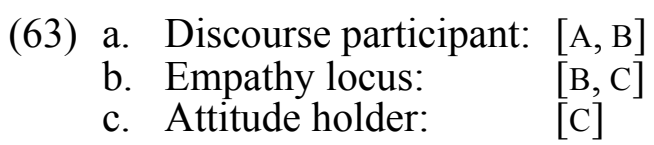

The [B] feature shared by discourse participants and empathy loci expresses the speaker component crucial to both cases. Discourse participants are directly defined by the speaker, and empathy loci are participants with whom the speaker identifies. The [C] feature common to empathy loci and attitude holders corresponds to perspectival distance from the speaker: both - implicitly or explicitly - involve a perspective center different from the speaker.

The combination of these ingredients - single logophoric operator in the relevant domain, sharing of features by identical or adjacent logophoric centers on the hierarchy correctly predicts intervention effects only in the PCC and CLR configurations.
a. *OPLOG $[\mathrm{A}, \mathrm{B}, \mathrm{C}]$
b. ${ }^{*} \mathrm{OPLOG}_{[\mathrm{A}, \mathrm{B}, \mathrm{C}]}$
c. $\operatorname{OPLOG}_{[\mathrm{A}, \mathrm{B}, \mathrm{C}]}$

$\begin{array}{ll}{\left[\operatorname{la}_{\mathbf{C}}\right.} & \left.\operatorname{lui}_{[\mathrm{B}, \mathrm{C}]}\right] \\ {\left[\mathrm{me}_{[\mathrm{A}, \mathrm{B}]}\right.} & \operatorname{lui}[\mathrm{B}, \mathrm{C}] \\ {\left[\mathrm{me}_{[\mathrm{A}, \mathrm{B}]}\right.} & \left.\operatorname{la} \mathrm{la}_{\mathrm{C}}\right]\end{array}$
(CLR)
(PCC)

\section{Conclusion}

Based on new data disentangling binding and logophoricity, we have shown that the generalization capturing the distribution of clitics clusters in French and Spanish is the following: an accusative clitic cannot be clustered with a dative clitic if it refers to a logophoric center and is read de se. We derive this antilogophoricity effect from 
perspective conflicts, which we represent as intervention effects arising in a specific domain. This requires distinguishing between different types of logophoric centers (i.e. discourse participant, empathy locus, attitude holder) and ranking them on a hierarchy in which only two identical or adjacent elements compete when co-occurring in the same domain. This analysis furthermore provides a semantic motivation for intervention effects that have been postulated for PCC - we hypothesize that PCC also derives from perspective conflicts. More generally, this predicts that intervention effects can arise when the relevant types of logophoric elements co-occur. Future work should examine how this can shed light on the behavior of long distance reflexives and other logophoric elements.

\section{References}

Adger, David \& Daniel Harbour. 2003. The syntax and syncretisms of the Person Case Constraint. Ms. Queen Mary, University of London and MIT.

Adger, David \& Daniel Harbour. 2007. Syntax and syncretisms of the Person Case Constraint. Syntax 10. 2-37.

Albizu, Pablo. 1997. The Syntax of Person Agreement. Los Angeles, CA: USC dissertation.

Anagnostopoulou, Elena. 2002. Case 17. Clitic Doubling. SYNCOM project.

Anagnostopoulou, Elena. 2003. The syntax of ditransitives. Evidence from clitics. Berlin: Mouton de Gruyter.

Anagnostopoulou, Elena. 2005. Strong and weak person restrictions. In Heggie, Lorie \& Francisco Ordóñez (eds.), Clitic and affix combinations - Theoretical perspectives, 199-235. Amsterdam. John Benjamins.

Anand, Pranav. 2006. De de se. Cambridge, MA: MIT dissertation.

Baker, Mark. 1988. Incorporation. A theory of grammatical function changing. University of Chicago Press.

Baker, Mark. 1996. The polysynthesis parameter. Oxford: Oxford University Press.

Béjar Susana \& Milan Rezac, 2003. Person licensing and the derivation of PCC effects. In Pérez-Leroux, Ana Teresa \& Yves Roberge (eds.), Romance linguistics, 49-62. Amsterdam: John Benjamins.

Bianchi, Valentina. 2003. On the syntax of personal arguments. Paper presented at the XXIX Incontro di Grammatica Generativa, Urbino.

Bhatt, Rajesh \& Radek Šimík. 2009. Variable binding and the Person-Case Constraint. $25^{\text {th }}$ Annual Meeting of the Israel Association for Theoretical Linguistics (IATL 25). Ben Gurion, University of the Negev.

Blake, Barry J. 1990. Relational grammar. London: Routledge.

Boeckx, Cedric. 2000. Quirky agreement. Studia Linguistica 54. 354-380.

Bonet, Eulàlia. 1991. Morphology after syntax. Pronominal clitics in Romance. Cambridge, MA: MIT dissertation.

Bonet, Eulàlia. 1994. The Person-Case Constraint. A morphological approach. In Harley, Heidi \& Colin Phillips (eds.) MIT working papers in linguistics 22. The morphologysyntax connection, 33-52. Cambridge, MA: MITWPL.

Charnavel, Isabelle. 2014. Exempt anaphors and logophoricity in French. Ms. Harvard 
University. Available at http://ling.auf.net/lingbuzz/002683.

Chierchia, Gennaro. 1989. Anaphora and attitudes de se. In Bartsch, Renate, Johan van Benthem, \& Peter van Emde Boas (eds.), Semantics and contextual expressions, 1-31. Dordrecht: Foris.

Chomsky, Noam. 1995. The minimalist program. Cambridge, MA: MIT Press.

Chomsky, Noam. 1998 [2000]. Minimalist inquiries, Ms., MIT. Published as 'Minimalist Inquiries: The framework'. In Martin, Roger, David Michaels, \& Juan Uriagereka (eds.), Step by Step. Cambridge, MA: MIT Press, 89-156.

Clements, George N. 1975. The Logophoric pronoun in Ewe. Its role in discourse. Journal of West African Languages 10. 141-177.

Cuervo, María Cristina. 2003. Datives at large. Cambridge, MA: MIT dissertation.

Demonte, Violeta. 1995. Dative alternation in Spanish. Probus 7.1. 5-30.

Dubinsky, Stanley W. \& Robert Hamilton. 1998. Epithets as antilogophoric pronouns. Linguistic Inquiry 29(4). 685-693.

Franco, Jon \& Susana Huidobro. 2008. Ethical datives, clitic doubling and the theory of pro. In Bruhn de Garavito, Joyce \& Elena Valenzuela (eds.) Proceedings of the 10th Hispanic Linguistics Symposium. Somerville, MA: Cascadilla Proceedings.

Hagège, Claude. 1974. Les pronoms logophoriques [logophoric pronouns]. Bulletin de la Société Linguistique de Paris 69. 287-310.

Haspelmath, Martin. 2004. Explaining the ditransitive person-role constraint: A usagebased approach, elanguage.net/journals/constructions/article/download/

3073/3052 (5 October 2013)

Heck, Fabian \& Marc Richards, 2007. A probe-goal approach to agreement and incorporation restrictions in Southern Tiwa. In Trommer, Jochen \& Andreas Opitz (eds.), 12 many: One-to-many relations in grammar, 205-239. University Leipzig.

Huang, C.-T. James \& Cheng-Sheng Luther Liu. 2001. Logophoricity, attitudes and ziji at the interface. In Cole, Peter, Gabriella Hermon \& C.-T. James Huang (eds.), Long distance reflexives, syntax and semantics 33. 141-195. New York: Academic Press.

Jouitteau, Mélanie \& Milan Rezac, 2008. The French ethical dative, 13 syntactic tests. Bucharest Working Papers in Linguistics, IX (1): 97-108.

Kayne, Richard. 1975: French syntax: the transformational cycle. Cambridge, MA: MIT Press.

Kayne, Richard. 2000. Person morphemes and reflexives in Italian, French and related languages. Parameters and universals. 131-162. Oxford/New York: Oxford University Press

Koopman, Hilda \& Dominique Sportiche. 1989. Pronouns, logical variables and logophoricity in Abe. Linguistic Inquiry 20. 555-589.

Kratzer, Angelika. 2009. Making a pronoun. Fake indexicals as windows into the properties of pronouns. Linguistic Inquiry 40. 187-237.

Kuno, Susumu. 1987. Functional syntax. anaphora, discourse and empathy. Chicago: University of Chicago Press.

Maling, Joan. 1984. Non-clause bounded reflexives in modern Icelandic. Linguistics and Philosophy 7. 211-41.

Marantz, Alec. 1993. Implications of asymetries in double object constructions. In Mchombo, Sam (ed.), Theoretical aspects of Bantu grammar, 113-150. Stanford, CA: CSLI Publications. 
Moltmann, Friederike. 2006. Generic one, arbitrary PRO, and the first person. Natural Language Semantics 14. 257-81.

Ormazabal, Javier \& Juan Romero. 2002. Agreement restrictions. Ms., University of the Basque Country and University of Alcalá, Spain.

Ormazabal, Javier \& Juan Romero. 2007. The object agreement constraint. Natural Language and Linguistic Theory 25. 315-347.

Oshima, David Y. 2007. On empathic and logophoric binding. Research on Language and Computation 5(1). 19-35.

Pearson, Hazel. 2015. The interpretation of the logophoric pronoun in Ewe. Natural Language Semantics 23. 77-118.

Perlmutter, David M. \& Paul Postal. 1983 The relational succession law. In Perlmutter, David (ed.) Studies in Relational Grammar 1. 30-80. Chicago: University of Chicago Press.

Reinhart, Tanya. 1983: Anaphora and semantic interpretation. Chicago, IL: University of Chicago Press.

Reinhart, Tanya. 2000. The theta system. Syntactic realization of verbal concepts. Utrecht. UiL OTS Working Papers.

Reinhart, Tanya \& Eric Reuland. 1993. Reflexivity. Linguistic Inquiry 24.4. 657-720.

Rezac, Milan. 2003. The fine structure of cyclic Agree. Syntax 6. 156-182.

Rezac, Milan. 2006. Phi-agree and theta-related case. http://loargann.batcave.net/

index.html (18 September 2013)

Roca, Francesc. 1992. On the licensing of pronominal clitics. The properties of object clitics in Spanish and Catalan. Barcelona, Spain: Universitat Autònoma de Barcelona MA thesis.

Roelofsen, Floris. 2010. Condition B effects in two simple steps. Natural Language Semantics 18. 115-140.

Rosen, Carol. 1990. Rethinking Southern Tiwa: the geometry of a triple agreement Language. Language 66. 669-713.

Ruwet, Nicolas. 1990. En et $y$ : deux clitiques pronominaux antilogophoriques [en and $y$ : two antilogophoric pronominal clitics]. Langages 97. 51-81.

Schlenker, Philippe. 2003. Indexicality, logophoricity, and plural pronouns. In Lecarme, Jacqueline (ed.), Research on Afroasiatic grammar, 409-428. Amsterdam: J. Benjamins.

Sells, Peter. 1987. Aspects of logophoricity. Linguistic Inquiry 18. 445-79.

Sportiche, Dominique. 1996. Clitic constructions. In Rooryck, Johan \& Laurie Zaring (eds.) Phrase structure and the lexicon. 213-277. Dordrecht: Kluwer.

Stowell, Timothy. 1981. Origins of phrase structure. Cambridge, MA: MIT dissertation.

Sundaresan, Sandhya. 2012. Context and (co)reference in the syntax and its interfaces. Tromsø/Stuttgart, Norway/Germany: University of Tromsø/University of Stuttgart dissertation. 